\title{
Green Highway for Malaysia: A Literature Review
}

\author{
Fatin Najwa Mohd Nusa ${ }^{1}$, Intan Rohani Endut ${ }^{2}$, Roshana Takim ${ }^{3}$ and Siti Zaharah Ishak ${ }^{1}$ \\ 1. MITRANS (Malaysia Institute of Transport), Mara University of Technology, Shah Alam 40450, Malaysia \\ 2. Faculty of Civil Engineering, Mara University of Technology, Shah Alam 40450, Malaysia \\ 3. Faculty of Architecture, Planning and Surveying, Mara University of Technology, Shah Alam 40450, Malaysia
}

\begin{abstract}
This paper reviewed on the green highway definition and green highway terminology to improve knowledge and awareness of green highway for highway construction projects. Moreover, this paper discussed briefly on the rating system for green highway by highlighting various eight rating systems for green highway. This study adopted the secondary data from previous research and findings on green highway construction from all over the world. With regard to published articles on green highways, the outcome of the paper will examine several major issues in green highway which are the definition of green highway, terminology used for green highway aspects, green highway initiatives and green highway rating systems from all over the world.
\end{abstract}

Key words: Literature review, green highway, definition, terminology, rating system.

\section{Introduction}

People need highways to stay in connection to daily lives [1]. As an uppermost infrastructure, highway plays its role as a "backbone" of the nation's social and economic development of the country [2]. But in early 1960s, construction projects including the highway construction projects seem to affect the environment, resources, raw materials and people [3]. The initial research and development on green highway technology was found at year 2002 in United States of America [4], while in Malaysia, National Green Technology Plan was launched on July 24, 2009 as a main agenda to promote green technology initiatives in the country development. One of the key issues that have been brought into discussion is the development of sustainable green highway for the future needs. Different models, framework and sustainable rating system have been put forward [1, 5-13] which mostly relate to the development of sustainable green highway. However, the need to be able to quantify the consideration of the environment impact towards sustainable green highway was still

Corresponding author: Fatin Najwa Mohd Nusa, M.Sc. candidate, researcher, research field: construction management. E-mail: fatinnajwanusa_89@yahoo.com. undermined [14].

Highway is one example of thousands infrastructure projects. Each of infrastructure projects requires sustainability aspects consideration. However, a green highway needs more attention and awareness from all parties such as the highway concessions and drivers, and the most important is the local authority to enhance the sustainable green concept of highway design which will be sustained at the life cycle basis [15]. Therefore, green highway constructions need a green highway assessment system to boost sustainability practice [16]. Recently, the number of publications and articles on sustainability infrastructure has rapidly increased as year 2013 was the latest in publishing research findings on the related issue. Researchers around the world have taken into account the sustainability issues regarding the highway construction projects in order to promote balance among economic, social, and environmental development. Throughout the analytical overview of existing research conducted, definition of green highway itself is different from the perspective of each researcher. In addition, a state-of-the-art review approach in this research would help in making different research approaches, findings and ideas for 
future research and also theory developed in that particular area.

As the highway system mellows in Malaysia, it is crucial to give an accentual action on improving the transportation strategies of highway construction that covers the green aspects to give an invasive movement to the government policies, create societal benefits and improve the economy since highway system is having a strong interconnection to all alternative modes of transportation.

Current studies of green highway addressed various green initiatives to improve our environment. However in Malaysia, initiatives and efforts are only focusing on the green building projects. Therefore, it is essential to be able to quantify the importance of green highway rating system and green highway initiatives in order to minimize the pollution to the environment and improve the environment, zero or low greenhouse emission, safe highway for use, and promote healthy, conserve the energy usage and natural resources, and finally promote the use of renewable resources.

This paper is only focused on previous research published on the related topic such as journals, conference papers, books and articles on highway construction that examine the previous research regarding to green highway aspects and element of the highway construction projects. Throughout the development of this paper, research area in the particular review needed perhaps will help in evolving ideas and knowledge for future research in green highway. However, focus lies on the rating system for highway construction projects because very limited mention can be found in the literature about the assessment of green highway construction [1]. As a result of this situation, key findings of studies on green highway definitions, terminology, aspects and elements are included in the review.

\section{Green Highway Definition}

The lifecycle of a highway construction is supported by the planning, design, construction and maintenance processes. Throughout the analytical overview of existing research conducted by other researcher previously, the definition of green highway itself is different from the perspective of each researcher and organization body. Following elaborate findings of various definitions for green highway, the findings of the definition are summarised in Table 1.

The Malaysia Highway Authority [2] has defined green highway by following aspects: "the watershed driven storm water management; life cycle energy and emission reduction; recycle, reuse and renewable; conservation and ecosystem management and overall

Table 1 Definition of green highway.

\begin{tabular}{|c|c|c|}
\hline \# & Country & Definition \\
\hline 1 & Malaysia [2] & $\begin{array}{l}\text { "Green highway can be defined as: the watershed driven storm water management; life cycle energy } \\
\text { and emission reduction; recycle, reuse and renewable; conservation and ecosystem management and } \\
\text { overall societal benefits.” }\end{array}$ \\
\hline 2 & United States [17] & “Green highway is an initiative to promote the use of cleaner fuels.” \\
\hline 3 & United States $[18,19]$ & $\begin{array}{l}\text { "Green highway is defined by an effort to go "beyond compliance” and leave the project area 'better } \\
\text { than before' through community partnering, environmental stewardship and transportation network } \\
\text { improvements in safety and functionality.” }\end{array}$ \\
\hline 4 & Malaysia [16] & $\begin{array}{l}\text { "Green highway is a roadway design based on a relatively new concept for roadway design that } \\
\text { integrates transportation function and ecology." }\end{array}$ \\
\hline 5 & United States [20] & $\begin{array}{l}\text { "Green highway includes more sustainable practices than modern construction techniques, and } \\
\text { consists of maximizing the lifetime of a highway.” }\end{array}$ \\
\hline 6 & Singapore [5] & $\begin{array}{l}\text { "Green highways or green roads are defined as roadway project that has been designed and } \\
\text { constructed to a level of sustainability that is substantially higher than current common practices.” }\end{array}$ \\
\hline 7 & India [21] & $\begin{array}{l}\text { "A green highway is the highway constructed using materials that emit no or low concentration of } \\
\text { pollutants and are environmental friendly." }\end{array}$ \\
\hline 8 & China [22] & $\begin{array}{l}\text { "Green highways are defined as the approaches for helping developers achieve friendly environment, } \\
\text { ecological responsiveness and social responsibility to improve long-term profitability and gain } \\
\text { sustained competitive advantage.” }\end{array}$ \\
\hline
\end{tabular}


societal benefits”.

Green highway is defined by the Washington Department of Transportation [17] as: “an initiative to promote the use of cleaner fuels". This definition refers to the research and innovation of electric vehicle fast charging stations at the selected interurban highways.

Green Highway Partnership [18] defined "green highway” as: “an effort to go 'beyond the compliance' and leave the project area 'better than before' through community partnering, environmental stewardship and transportation network improvements in safety and functionality”.

Ismail et al. [16] determined the definition of "green highway" as: "a roadway design based on a relatively new concept for roadway design that integrates transportation functionality and ecology”. Green highway according to Ismail et al. [16] is having a role in sub-elements of ecology, landscaping, waste reduction, materials, water conservation and energy efficiency in making highways green.

Other authors like Bryce [20] have considered the "green highway" to include more sustainable practices than modern construction techniques, and consist of maximizing the lifetime of a highway. Krebs [19] has limited the "green highway" as an effort to leave the project area better than before through community partnering, environmental stewardship, and transportation network improvement in safety and functionality. Singh et al. [5] set the definition for "green highways" as a roadway project that has been designed and constructed to a level of sustainability that is substantially higher than current common practices. Reddy [21], on the other hand, had fixed that "green highway" is the highways constructed using materials that emit no or low concentration of pollutants and are environmental friendly. Zhang et al. [22] proposed "green highways” as the approaches for helping developers achieve friendly environment, ecological responsiveness and social responsibility to improve long-term profitability and gain sustained competitive advantage.

Each of the aforementioned definition of green highway listed above addresses similarity and difference regarding to the different green highway approach. Based on the reviews above, the definition of green highway in this research shall be: "Green highway is defined as the use of recycled materials, ecosystem management, and energy reduction, increasing the water quality of storm water runoff and maximizing the societal benefits” from Malaysia Highway Authority.

The reason why the above mentioned definition adopted for this research is to make sure that this research is suitable and in line with the recent Malaysia highway construction practice by the MHA (Malaysia Highway Authority). Malaysia Highway Authority is an organization that is responsible to supervise and execute the design, construction and maintenance of highways in Malaysia as determined by the Federal Government of Malaysia. To be specific to supervise and execute the design, construction and maintenance of RSA's (rest and service areas), other facilities may be deemed necessary along highways and other dues from facilities along highways to plan and carry out research to ensure efficient utilization of highways and other facilities along highways, and generally to do everything for the betterment and proper use of highways and other facilities along highways for Malaysia.

\section{Terminology Used for Green Highway Aspects}

There are terminologies or a system of words used to name broad topics in green highway in which one of them contains diversified aspects in highway construction. Five broad topics are listed below that cover green highway aspects.

\subsection{Watershed Driven Storm-Water Management}

Watershed driven storm water management is defined as a process of reducing the runoff water from 
the highway, or in another words, treating the runoff water as well as diverting the runoff water to the place where the water can be infiltrated into the ground water table [2]. Some examples of watershed driven storm water management technologies in highway construction are bio-slopes, bio-swales, bio-retention cell, permeable pavers, vegetated filter strip and street trees, which are widely used in United States, and the initiative to develop suitable but yet economical with a proper design and analysis for storm-water management and treatment alongside the highway [23].

\subsection{Life Cycle Energy and Emission Reduction}

Parallel to the Go Green Initiative, energy sectors play an important role for the economic growth. An example of life cycle energy and emission reduction technique is the replacement of cement in highway construction with fly ash or blast furnace slag or foundry sand or waste rubber tyres and rubber pieces that were proven to save energy about 6.4 billion gallons of gas every year [2]. However, recycling process needs a lot of energy in order to produce a new product.

\subsection{Recycle, Reuse and Renewable}

Usage of recycle materials derived from industrial by product is not only significantly in reducing the greenhouse gas emissions and reducing the energy consume by a highway but it also reduces the overall highway construction cost [2]. In European countries, the high tax rate for virgin material pits required in highway construction was proven to reduce the amount of highway construction waste material into the landfills [20]. Another benefit of recycle, reuse and renewable of highway construction material is increasing the water saving and reducing the carbon emission as well as reducing the air emission.

\subsection{Conservation and Ecosystem Management}

Underlined with the recent problems on the biodiversity crisis, Grumbine [24] believed that ecosystem management awakens the restorative action techniques that will emphasize a healthy future environment for the entire biotic life. Examples of conservation and ecosystem management in green highway are the wildlife buffer zones and also animal crossing structures and underpass that concern on reducing the vehicle wildlife collision [2].

\subsection{Overall Societal Benefits}

In order to achieve the sustainability in highway construction, overall societal benefits should be taken into deep consideration because it has an effect upon the local economies development [25]. According to Schweitzer and Tonn [26], there are three types of sub-element under societal benefits factors which are environmental benefits, economic benefits and social benefits that lie under a big scope of non-energy benefit. However, in highway construction project, a highway can be classified as a serviceable highway for the society if it is designed under the standard that can increase economy by supplying the good location for the economic growth with plenty of local jobs and affordable tax income to the community.

\section{Green Highway Rating System}

Highway construction industries in particular have significant impacts on the environment. Green highway rating system has been developed to address the sustainability elements for highway construction. In this research, review of eight green prominent emerging highway rating systems has been highlighted during the literature review process which are the Malaysia Highway Index; EEi (Energy Efficient Index); INVEST (Infrastructure Voluntary Evaluation Sustainability Tools); ENVISION (Sustainable Infrastructure Rating System); Green Road Rating System; GreenLITES (Green Leadership In Transportation And Environmental Sustainability); $\mathrm{BE}^{2} \mathrm{ST}$-in-Highways; and I-LAST (Illionois-Livable and Sustainable Transportation). 
The review shows that there are similarities between each of the rating system. Precise and clear comparisons of the criteria in each green highway rating system are tabulated in Table 2 which shows the related item related to energy efficiency; energy and atmosphere; project lifecycle; water and waste water energy; recycle materials and lightings.

Malaysia Highway Index and Energy Efficient Index are the rating systems that proposes green highway in the Malaysia context. Both of the rating system express the need of energy plan for GPC (green performance) strategies [27, 28]. Each of the rating system deals with categories that suit for different phase and different criteria of green highway construction.

The selection for the right category of green highway is important in each of the highway construction phase to underline each criterion of green highway. Environment category; water quality and use category; energy category and materials category are implied in each rating system.

Ismail et al. [16] concentrate on the new concept of roadway design that will benefit the users and the ecosystem while, in the book of "Preliminary Guide to Nurture Green Highway in Malaysia” by Malaysia Highway Authority [2], the focus lies on the usage of recycle material in highway construction, the protection of bio-life through ecosystem management, energy saving applications, runoff water quality and the benefit to the economy and society. While Bryce [20] reports that green highway is a recent technology of highway construction but it is not yet fully discovered. However, Krebs [19] and Green Highway Partnership [18] claim that, green highway is an initiative of the project team to deliver good condition of project area in terms of safety and environment protection after the completion of the construction.

\section{Key Findings}

Current studies of green highway address various topics to discuss. Bryce [20], Malaysia Highway Authority [2] and Talati et al. [4] classify green highway in five broad topics which are watershed driven storm water management; life cycle energy and emissions reduction; recycle, reuse and renewable; conservation and ecosystem management and finally overall societal benefits. Furthermore, Talati et al. [4] highlight the green highway's consideration at the construction stage and maintenance stage. In addition, Ismail et al. [16] look at elements and aspects at the side of transportation functionality and ecology and finally come out with elements and sub-elements of green highway which are ecology, landscaping, waste reduction, materials, water conservation and energy efficiency.

Moreover, Tsai and Chang's [12] study investigates the levels of difficulty for sustainable roadway design for each of sustainable roadway design items by taking roadway as an example. However, Saqr and Musa [31] discuss the energy consumption trends using a novel concept of VAWT (vertical-axis wind turbine) to promote sustainable and green energy source for highway lighting purpose.

Table 2 Rating system for green highway.

\begin{tabular}{lll}
\hline$\#$ & Previous rating system & Criteria \\
\hline 1 & Malaysia Highway Index [28] & Energy efficiency \\
2 & EEi [27] & Energy efficiency; energy and atmosphere \\
3 & INVEST [15] & Project lifecycle (design a custom on web based interface) \\
4 & ENVISION [8] & Water and waste water energy \\
5 & Green Roads Rating System [29] & Energy efficiency \\
6 & GreenLITES [30] & Energy and atmosphere \\
7 & BE ${ }^{2}$ ST-in-Highways [10] & Recycle materials in pavement \\
8 & I-LAST [8] & Lighting \\
\hline
\end{tabular}


Since almost all efforts and initiatives for the sustainable development are focused only for building [16], the following highway rating system mentioned will certainly give some ideas to alleviate green highway construction projects. On the other hand, green highway construction rating system can be seen to promote durable long-lasting sustainable construction. Clevenger et al. [8] and Lee et al. [32] compare and explore sustainable infrastructure rating systems which are $\mathrm{BE}^{2} \mathrm{ST}$-in-Highways, ENVISION, GreenLITES, Greenroads, I-LAST and INVEST.

\section{Conclusions and Recommendations}

This paper only reviews the literature on highway construction from overseas project, organizations, journals paper and publications from Malaysia, Washington, Oregon, California, United States, Singapore, Indian and China to get a clear view to cover on green highways aspects and elements. The review of the literature search in this paper can be summarized as below:

- At the beginning of this paper, the researcher diagnosed on the green highway definitions by other country and organizations, and finally came out with suitable and applicable definition of green highway in this research to conclude the findings;

- Then, the researcher briefly explained five terminologies that cover green highways aspects which are the watershed driven storm water management; life cycle energy and emission reduction; recycle, reuse and renewable; conservation and ecosystem management and overall societal benefits;

- Next, the researcher listed the rating systems for green highway and green highway initiatives in order to address the sustainability criteria for the green highway construction;

- Finally, the researcher indicated the key findings of the paper by mentioning other research findings regarding to the highway construction.

This paper can be expanded into several area for further research and knowledge sharing in the green highway research as follows:

- Here, the researcher established a preliminary green highway literature but in the future personal communication with the highway concessions can be a subject matter for further research in order to get clear current practice by the authority;

- The metrics involved with evaluating green highways have not been refined and will require further research on a rating system to understand the important of developing a dynamic system that can be changed to incorporate future technologies;

- There is a critical need to continue the research towards developing new and beneficial technologies to sustain Malaysia's infrastructure;

- The development of a rating system may help build up current need for research in green highway;

- The research and implementation of rating system will assist in advancing research towards beneficial applications and the communities will apparently know the benefit of the green highway design;

- Lifecycle analysis tools are required in order to get clear understanding on technologies that benefit a green highway;

- Case study approach can be conducted in the future order to make legally valid the green highway applications in highway construction.

\section{References}

[1] Huang, R., and Yeh, C. 2008. "Development of an Assessment Framework for Green Highway Construction." Journal of Chinese Institute Engineering 31 (4): 573-85.

[2] Malaysia Highway Authority. 2010. Preliminary Guide to Nurture Green Highway in Malaysia. 1st ed. Malaysia: Lembaga Lebuhraya Malaysia.

[3] Ogola, P. F. A. 2007. "Environmental Impact Assessment." In Proceedings of Short Course II on Surface Exploration for Geothermal Resources, 1-16.

[4] Talati, V. A., Mehta, J., and Six, K. 2013. "Green Highways: A Future Need." Paripex-Indian Journal of Research 2 (3): 109-11.

[5] Singh, R. G., Gupta, A. K., and Ogra, A. 2011. "Greenroads: A Portrait of Sustainable Design and 
Construction for Indian Roads.” In Proceedings of 2011 2nd International Conference on Construction and Project Management, 264-8.

[6] Singh, R. K., Murty, H. R., Gupta, S. K., and Dikshit, A. K. 2009. "An Overview of Sustainability Assessment Methodologies." Ecological Indicators 9 (2): 189-212.

[7] Martin, A., and Sherington, J. 1997. "Participatory Research Methods-Implementation, Effectiveness and Institutional Context." Agricultural Systems 55 (2): 195-216.

[8] Clevenger, C. M., Ozbek, M. E., and Simpson, S. 2013. "Review of Sustainability Rating Systems Used for Infrastructure Projects." Presented at 49th ASC (Associated Schools of Construction) Annual International Conference, Fort Collins, Colorado.

[9] Kane, A., and Allen, J. 2009. "The Zofnass Rating System." Cambridge, Massachusetts. Accessed January 9, 2013. http://www.gsd.harvard.edu/research/research_ centers/zofnass/.

[10] Miller, J. M. 2012. Institute for Sustainable Infrastructure Envision Rating System Need for an Infrastructure Sustainability Rating System. Raleigh: Institute for Sustainable Infrastructure.

[11] Eriksson, P. E., and Westerberg, M. 2011. "Effects of Cooperative Procurement Procedures on Construction Project Performance: A Conceptual Framework." International Journal of Project Management 29 (2): 197-208.

[12] Tsai, C. Y., and Chang, A. S. 2012. "Levels of Difficulty for Sustainable Roadway Design." Advanced Material Research 453: 543-7.

[13] Kang, M. W., Jha, M. K., and Schonfeld, P. 2012. "Applicability of Highway Alignment Optimization Models." Transportation Research Part C: Emerging Technologies 21 (1): 257-86.

[14] Das Mulmi, A. 2009. "Green Road Approach in Rural Road Construction for the Sustainable Development of Nepal." Journal of Sustainable Development 2 (3): 149-65.

[15] Cui, Q., Zhu, X., Whitten, L., and Dason-Deane, R. 2011. "Innovative Contracting Strategies for Combating Climate Change." Maryland. Accessed January 9, 2013. http://www.roads.maryland.gov/OPR_Research/MD-11-S P009B4G_Innovative-Contracting-Strategies-Report .pdf.

[16] Ismail, A., Rozana, Z., Sani, B. A., Foo, K. S., Naadia, M. A., Salfiza, Y. Y., et al. 2013. "Fundamental Elements of Malaysia Green Highway." Applied Mechanics and Materials 284-287: 1194-7.

[17] Washington Department of Transportation. 2013. "Leadership Now for Sustainable Highway Tomorrow." Washington Department of Transportation. Accessed January 9, 2013. http://www.westcoastgreen highway.com/.

[18] Green Highway Partnership. 2008. "Green Highways Partnership Fact Sheet." Green Highway Partnership. $\begin{array}{llll}\text { Accessed January } & 913 .\end{array}$ http://www.greenhighways.org.

[19] Krebs, S. W. 2009. "Green Highway: What Makes a Highway Green?." Presented at WAPA (Wisconsin Asphalt Pavement Association) Annual Conference, Middleton, Wisconsin.

[20] Bryce, J. M. 2008. "Developing Sustainable Transportation Infrastructure." Washington. Accessed January 9, 2015. http://www.wise-intern.org/journal/2008/JamesBryceFina 1.pdf.

[21] Reddy, M. A. 2011. "Need of Green Highways in India for Sustainable Development." Prestented at 6th Symposium on National Frontiers of Engineering, West Bengal, India. Accessed January 9, 2013. http://www.iith.ac.in/ natfoe/images/abstract/Abstract-Pr of. Amaranatha Reddy_Green Highways.pdf.

[22] Zhang, X., Shen, L., Wu, Y., and Qi, G. 2011. "Barriers to Implement Green Strategy in the Process of Developing Real Estate Projects." Open Waste Management Journal 4: 33-7.

[23] GHP (Green Highway Partnership). 2009. Green Highways and Green Streets for 21st Century Infrastructure: Strategies, Technologies and Funding. Malaysia: GHP.

[24] Grumbine, R. E. 2013. "What Is Ecosystem Management?.” Conservation Biology 8 (1): 27-38.

[25] Trading Economics. 2013. "Malaysia Infrastructure." Trading Economics. Accessed December 12, 2013. http://www.tradingeconomics.com/malaysia/gdp-growthannual.

[26] Schweitzer, M., and Tonn, B. 2002. "Non-energy Benefits from the Weatherization Assistance Program: A Summary of Findings from the Recent Literature." United States. Accessed Jan. 9, 2013. http://www.osti.gov/bridge.

[27] Zakaria, R., Majid, M. Z. A., Zin, R. M., Hainin, M. R., Puan, O. C., Yaacob, H., et al. 2012. "Identification of Energy Efficiency Criteria for Malaysia Green Highway." In Proceeding of 8th Asia Pacific Structural and Construction Engineering Conference and 1 st International Conference, 2-4.

[28] Zakaria, R., Seng, F. K., Zin, R. M., Hainin, M. R., Puan, O. C., Derin, N., et al. 2013. "Energy Efficiency Criteria for Green Highways in Malaysia." Journal of Technologies 3: 91-5.

[29] Eisenman, A. P. 2012. Sustainable Streets and Highways: An Analysis of Green Roads Rating Systems. USA: Georgia Institute of Technology. 
[30] Fortmann, J., Dahhan, A., Wanner, R., and Aquino, M. 2010. Illinois-Livable and Sustainable Transportation Rating System and Guide. United States: Illinois Department of Transportation.

[31] Saqr, K. M., and Musa, M. N. 2011. “A Perspective of the Malaysian Highway Energy Consumption and Future
Power Supply.” Energy Policy 39 (6): 3873-7.

[32] Lee, J., Edil, T. B., Benson, C. H., and Tinjum, J. M. 2010. "Use Of $B E^{2} S T$-in-Highways for Green Highway Construction." In Proceedings of ASCE (American Society Civil Engineers) 141st Annual Civil Engineering Conference, 480-94. 